Elita Nìmande, Dr. iur.,

Latvijas Universitātes Juridiskā fakultāte, Latvija

\title{
KRIMINĀLISTISKĀS TAKTIKAS KĀ KRIMINĀLISTIKAS SISTĒMAS ELEMENTA BŪTİBA
}

\section{THE ESSENCE OF CRIMINALISTIC TACTICS AS THE ELEMENT OF THE SYSTEM OF CRIMINALISTICS}

\begin{abstract}
Summary
The article is devoted to the problem of understanding criminalistic tactics including the optimal way of performing investigative activities provided for in the Republic of Latvia Law on Criminal Procedure and applied during the investigation of criminal offences. It is pointed out that the content and logical volume of the notion 'criminalistic tactics' is composed of some specific characteristics of criminalistic activities, and criminalistic tactics could be defined as a chapter of special part of criminalistics theory describing regularities in performing investigative activities.
\end{abstract}

Atslēgvārdi: krimināltiesiskās zinātnes, kriminālistika, kriminālistiskā taktika, izmeklēšanas darbības, noziedzīgu nodarïjumu izmeklēšana

Keywords: criminal law sciences, criminalistics, forensic science, criminalistic tactics, investigative activity, investigation of criminal offences

Nav noliedzams krimināltiesisko zinātṇu jomas nozīmīguma pieaugums un jauni izaicinājumi šajā jomā gan Latvijā, gan citur Eiropā, to skaitā teorētisku sistēmiskas nozīmes jautājumu aktualitāte. Lai gan Latvijā kopš 2001. gada radīta situācija, ka kriminālistika kā juridiskās (kopš 2018. gada - tiesību zinātne ${ }^{1}$ ) zinātnes apakšnozare izslēgta no krimināltiesību apakšnozares, tomēr nevar noliegt kriminālistikas jomā apkopoto zināšanu satura ciešo saikni ar krimināltiesiskajām zinātnēm. Lìdz ar to aktuāls ir jautājums par kriminālistisko zināšanu sakārtotību un kriminālistikas (kā zinātnes) sistēmas elementu izpratni.

Kā zināms, kriminālistikas sevišķo (priekšmetisko) daļu veido zināšanu kopums par noziedzīgu nodarījumu izmeklēšanas likumsakarībām; šīs zināšanas veido sistēma, kas sastāv no trim elementiem: 1) noziedzīga nodarījuma pēdu rašanās kā sagaidāms notikums (kriminālistiskās tehnikas joma), 2) izmeklēšanas darbību veikšana kā pierādījumu iegūšanas pamatveids (kriminālistiskās taktikas joma), 3) noziedzīgu nodarījumu izmeklēšanas zinātniska organizēšana (kriminālistiskās metodikas joma) ${ }^{2}$.

Ministru kabineta 23.01.2018. noteikumu Nr. 49 "Noteikumi par Latvijas zinātnes nozarēm un apakšnozarēm" pielikuma 5.5. apakšpunkts.

2 Sỉkāk sk., piemēram, Терехович В. Н. Теория криминалистики. Общая часть. Рига: [b. i.], 2015, c. $28-30$. 
Pēdējo gadu publikācijās kriminālistikā reti aktualizēts jautājums par kriminālistiskās taktikas būtību un tās pamatojumu, bet daži autori izteikuši apgalvojumus par terminu "tiesas taktika”, "advokātu taktika” u. tml. izmantošanas nepieciešamību kriminālistiskās taktikas ietvaros.

Raksta mērḳis ir izskaidrot un definēt kriminālistiskās taktikas būtību, izmantojot kriminālprocesuālo darbību paveida - izmeklēšanas darbību - būtības skaidrojumu.

Teorētisko zināšanu uzbūves logikā nepieciešama ne tikai zināšanu vispārināšana un sistematizācija, bet arī zināšanu iezīmēšana, iedalīšana īpašās grupās. Zinātniskajā izzināšanā tradicionāls zināšanu iezīmēšanas līdzeklis ir termins ${ }^{3}$. Par zinātniskās izzināšanas dinamiku un mūsdienu attīstības līmeni noteiktā jomā var spriest pēc tās terminologijas izmaiṇām, kuru izmanto vienā vai otrā zinātniskās darbības sfēēā. Šì prasība attiecināma arī uz kriminālistikas teoriju.

Jau no 20. gadsimta sākuma pētnieki - kriminālisti savos darbos sāka izmantot terminu "kriminālā taktika" ${ }^{4}$ S Šim terminam ir sava attīstības specifika. Pien,emts uzskatìt, ka idejas par "kriminālās taktikas" sadaḷas izveidi noziedzīgu nodarījumu izmeklēšanas jomā pamatlicējs ir vācu kriminālists Alberts Veingards (Albert Weingart, 1851-1914), kurš kriminālās taktikas ideju izklāstīja darbā "Kriminālā taktika. Rokasgrāmata noziegumu izmeklēšanā”. Būtu jāprecizē, ka šajā darbā A. Veingards, skaidrojot kriminālās taktikas būtību, ar to domāja ideju par kriminālpolicejisko taktiku. Šajā sakarā viṇš rakstīja: "Lai sekmīgi cīnītos, īpaši ar noziedzniekiem profesionāliem, vispirms nepieciešams noskaidrot, savākt, apvienot jau zināmos un izstrādāt jaunus cinnas un noziedznieku izsekošanas paṇēmienus, pie tam sistemātisks paņēmienu cinnai ar noziedzību, zinātniski objektīvu un praktiski pārbaudītu noziegumu izmeklēšanas veidu, vainīgo noskaidrošanas, pierādijjumu vākšanas, noziedznieka aizturēšanas un atmaskošanas pañēmienu izklāsts nav nekas cits kā kriminālpolicejiskā taktika, kas ir tāds pats nepieciešams noziegumu atklāšanas mākslas piederums, kā militārtaktika kara mākslā." ${ }^{5}$ Šo ideju vācu kriminālisti turpina attīstīt arī mūsdienās. ${ }^{6}$

Postpadomju valstīs termins "kriminālā taktika" tika attīstīts citādi. Līdz 20. gadsimta 30. gadiem kriminālistikas mācību grāmatās šis termins tika izmantots. ${ }^{7}$ Turpmāk tas pārveidojās par noziegumu izmeklēšanas taktiku ${ }^{8}$, izmeklēšanas taktiku un visbeidzot par kriminālistisko taktiku ${ }^{10}$. Kriminālistikas terminologijas unifikācijas

3 Termins (latīnu therminus - robeža) - vārds vai vārdu savienojums, kas nepārprotami atklāj zinātniska jēdziena jēgu, tā savstarpējo sakaru ar citiem jēdzieniem.

4 Taktika (no grieķu taktike - karaspēka izkārtošanas māksla) - militārmācības sadaḷa, kurā ietverta dažādu karaspēka veidu apakšvienību kaujas sagatavošanas un īstenošanas teorija un prakse.

5 Вейнгарт А. Уголовная тактика. Руководство к расслеАованию преступлений. Санктпетербург: Овруч, 1910, с. 3.

6 Kriminalistik Lexicon. Kriminalistik Verlag, Heidelberg, 1996, S. 187, Ackermann R., Clages H., Roll H. Handbuch der kriminalistik. Kriminalistik fuer Praxis und Ausbildung. 2 Auflage. Richard Boorberg Verlag, 2003.

7 Якимов И. Н. Криминалистика уголовная тактика. 2-е изА., Москва, 1929.

8 Криминалистика. Техника и тактика расследования преступлений. Учебник. Москва, 1938.

9 Васильев А. Н. Основы следственной тактики. Автореферат Аисс., Москва, 1960.

10 Винберг А. И. О научных основах криминалистической тактики. Правоведение. Но. 3. Москва, 1965. 
rezultātā mūsdienās kriminālistikas mācību grāmatās tiek izmantots tikai termins "kriminālistiskā taktika”. Terminologijas izmaiņas šajā kriminālistikas daļā notika ne tikai kriminālprocesa attīstības rezultātā, bet arī kā sekas priekšstatu izmaiņām par noziedzīgu nodarījumu izmeklēšanas būtību, robežu precizēšanai tām darbībām, kas vērstas uz ar noziedzīga nodarījuma notikumu saistīto apstākḷu noskaidrošanu, atškirīibu noskaidrošanai starp pirmstiesas izmeklēšanu, lietas izskatī̌̌anu tiesā un noziedzīgu nodarījumu izmeklēšanu un citiem darbības veidiem krimināltiesību piemērošanas jomā. Lai gan kriminālistiskās taktikas definīcijas atšķiras, visi kriminālistikas mācību grāmatu autori terminu "kriminālistiskā taktika" attiecina uz noziedzīgu nodarījumu izmeklēšanas jomu. Atšķirības definīcijās skaidrojamas ar autoru dažādiem priekšstatiem par noziedzīgu nodarījumu izmeklēšanas būtību.

Noziedzīga nodarījuma izmeklēšana (nejaukt ar pirmstiesas kriminālprocesa posmu - izmeklēšanu) ir cilvēku aktivitātes priekšmetiskā joma, kurā notiek izzināšanas process, kuram ir specifiska jaunu zināšanu iegūšanas tehnologija.

Pirmkārt, noziedzīga nodarījuma izmeklēšana ir profesionālās darbības paveids. ${ }^{11}$ Šis apstāklis nosaka to, ka noziedzīga nodarījuma izmeklēšanai ir normatīvi noteikts raksturs, t. i., konkrētā valstī tiek izmeklēti tikai tādi noziedzīgi nodarījumi, kuri aprakstīti konkrētas valsts krimināllikuma sevišķajā daḷā, un tādā kārtībā, kāda aprakstìta konkrētās valsts kriminālprocesa likumā. Tādējādi noziedzīgo nodarījumu izmeklēšanas normativitāte nosacīta ar konkrētas valsts krimināltiesību un kriminālprocesa avotu saturu. Noziedzīga nodarījuma izmeklēšana ir izzinoša darbība, kas virzìta uz noziedzīga nodarījuma un tā apstākḷu noskaidrošanu. Katrā valstī likumdevējs nosaka to ar noziedzīga nodarījuma notikumu saistìto apstākḷu apjomu un saturu, kuri aktuāli konkrētās valsts krimināltiesību piemērošanā. Tieši ticamu ziṇu esamība par apstākliem, kas saistīti ar noziedzīgo nodarījumu, ir pamats noziedzīgā nodarījuma notikuma krimināltiesiskai kvalifikācijai un taisnīgam krimināltiesisko attiecību noregulējumam konkrētā valstī. Ar noziedzīgo nodarījumu saistīto apstākḷu apjoms un saturs nosacìts ar konkrētas valsts krimināltiesību avotiem (krimināllikums, kriminālkodekss u. tml.), un tas laika gaitā var mainīties likumu jaunrades procesā. Ar noziedzīga nodarījuma notikumu saistītajiem apstākḷiem ir sarežgita teorētiskā konstrukcija ${ }^{12}$, jo šo apstākḷu atspoguḷojums materiālajā ìstenībā vienmēr ir komplekss un pastarpināts. ${ }^{13}$ Tāpēc noziedzīga nodarījuma veiksmīga izmeklēšana vienmēr objektīvi ir sarežğìta, un tai nepieciešama pietiekama profesionāla sagatavotība, t. i., ilgstošs teorētisko un praktisko mācību periods.

Otrkārt, noziedzīga nodarījuma izmeklēšana ar zinātnes līdzekḷiem ir zinātniskās izzināšanas darbības paveids. Tāpēc noziedzīga nodarījuma izmeklēšanas struktūras priekšmetiskais pamats ir izzināšanas objektu (ar noziedzīgu nodarījumu saistīto apstākḷu pēdas) sistēmas, izzināšanas darbību (izmeklēšanas darbības) sistēmas un zināšanu (sākotnējās un metodiskās zināšanas par noziedzīgu nodarījumu izmeklēšanu) sistēmas kopums. Kriminālistikas teorijā ar noziedzīga nodarījuma notikumu saistīto apstākḷu pēdu rašanās likumsakarības aprakstītas kriminālistiskās tehnikas

11 Profesionālā darbība - produktīva darbība noteiktā profesijā.

12 Sīkāk sk. Терехович B. Н., с. 59-101.

13 Ibid., c. 45-56. 
sadaļā, bet sākotnējo un metodisko zināšanu par noziedzīgu nodarījumu izmeklēšanu likumsakarības apkopotas kriminālistiskās metodikas sadalı̄ā.

Kriminālistikā izzinošo darbību sistēmai arī ir savas likumsakarības, un tā iedalāma īpašā jēdzienu grupā. Kriminālistisko zināšanu iegūšanas un uzbūves log̣ika prasa skaidri apzīmēt šo darbību apjomu un formulēt to saturu. Vispirms jān,em vērā tas, ka jebkura darbība pastāv kā konkrētu darbību kopums; šo darbību skaits un specifika atkarīga no darbības priekšmeta specifikas, darbïbas subjekta mērḳiem un tās īstenošanas nosacỉjumiem. Kriminālistiskajā izzināšanā darbību sistēmas īpatnība ir tā, ka noziedzīga nodarījuma izmeklēšanas apstākḷi vēsturiski vienmēr bijuši nosacīti kriminālprocesa aprakstā. Šãds apraksts parasti ir kodificēts un konkrētā valstī pastāv normatīiā akta veidā (Kriminālprocesa likums, Kriminālprocesa kodekss u. tmll.).

Kriminālprocesuālais apraksts ir kriminālprocesuālo darbību un to veikšanas nosacijjumu apraksts; šo nosacījumu îstenošana un ievērošana var novest pie taisnīga krimināltiesisko attiecību noregulējuma. Tāa arī ir zinātniskās izzināšanas darbības, kas virzīta uz būtiskāko sabiedrības vērtību kriminālprocesuālo aizsardzību, jēga. Katrā konkrētā valstī kriminālprocesā atspoguḷota konkrētās sabiedrības vēsturiskā pieredze krimināltiesisko attiecību taisnīga noregulējuma veida noteikšanā. Valstīs, kuras tiesisko attiecību jomā vēl attīstās, šis veids var būt dalẹeji vai pilnīgi patapināts. Tā, piemēram, bijušajās britu kolonijās jūtama anglosakšu tradīciju ietekme kriminālprocesā, postpadomju valstīs kriminālprocesam piemīt padomju republiku kriminālprocesu iezīmes, padomju kriminālprocesam ir vācu kriminālprocesa pazīmes u. tml. Šis fakts jāpieñem kā vēsturiski veidojies, bez salīdzinoša vērtējuma, vai tas ir labi vai slikti.

Latvijā tradicionāli par krimināltiesisko attiecỉbu subjektiem, no vienas puses, var uzskatīt valsti to pārstāvošo institūciju personā un, no otras puses, pieskaitāmu vai ierobežoti pieskaitāmu, 14 gadu vecumu sasniegušu fizisku personu. Kriminālprocesam Latvijā ir divi secīgi izvietoti posmi: pirmstiesas process (izmeklēšana un kriminālvajāšana) un lietas izskatī̌̌ana tiesā (iztiesāšanas process). Pirmstiesas procesa izmeklēšanas posmā tiek veiktas tādas kriminālprocesuālas darbïbas, kuras virzìtas uz krimināltiesiskā strīda priekšmeta noteikšanu, vainojamās personas noskaidrošanu un meklēšanu, tiesību nodrošināšanu uz aizstāvību, nepieciešamības gadijjumā piespiedu līdzekḷu piemērošana, kā arī citas kriminālprocesuālās darbības.

Starp kriminālprocesuālajām pamatdarbībām pirmstiesas procesa izmeklēšanas posmā būtu jāizcel uz noziedzīgā nodarījuma notikumu attiecināmo pēdu atrašana un kriminālprocesuāla nostiprināšana, noziedzīgā nodarījuma sastāva un citu ar nodarījumu saistīto apstākḷu esamības apstiprināšanai nepieciešamo pierādījumu savākšana un pārbaude. Tieši šã veida kriminālprocesuālo darbību īstenošana veido jebkura noziedzīga nodarījuma izmeklēšanas, t. i., ar noziedzīgu nodarijuma notikumu saistīto apstākḷu noskaidrošanas, būtību. Vēsturiski šo kriminālprocesuālo darbību grupu sauc par izmeklēšanas darbībām.

Latviešu valodā vārda "izmeklēšana" saknē ir vārds "meklēt", turpretim krievu un angḷu valodā vārda "izmeklēšana" (piemēram, angḷu investigation) saknē ir vārds "pēda" (anglu vestige). Arī noziedzīga nodarījuma notikums materiālajā vidē atspogul’ojas kā noziedzīga nodarījuma pēdas. Ar šo apstākli skaidrojama vārda "izmeklēšana” etimolog̣ija. Izmeklēšanas darbības ir kriminālprocesuālo darbỉbu paveids, un tās tieši 
virzītas uz to apstākḷu pēdu atklāšanu, kuri saistīti ar noziedzīga nodarījuma notikumu. Tāpēc izmeklēšanas darbības var definēt kā pirmstiesas izmeklēšanu veicējas personas darbības, kas tieši virzìtas uz ar noziedzīga nodarījuma notikumu saistīto apstākḷu noskaidrošanu.

Izdalot no kriminālprocesuālo darbību grupas atsevišķu darbību grupu - izmeklēšanas darbības, tiek sasniegta noteiktība ne tikai izmeklēšanas darbïbu izpratnē, bet arī izmeklēšanas darbību saturā un logiskajā apjomā. Izmeklēšanas darbību daba nosacīta ar to, ka, pirmkārt, izmeklēšanas darbības ir mērķtiecīgas darbības, t. i., tās vienmēr orientētas uz saprātīga mērķa sasniegšanu - noskaidrot apstākḷus, kas saistīti ar noziedzīgu nodarījumu; otrkārt, izmeklēšanas darbības ir vērtību un racionālas darbības, jo tās orientētas uz juridiskām vērtībām, t. i., uz noziedzīga nodarījuma notikuma un ar to saistìto apstākḷu juridisku izpratni. Izmeklēšanas darbību logisko apjomu un saturu tradicionāli nosaka normatīvi, t. i., izmeklēšanas darbību uzskaitījums un katras darbības saturs aprakstīts konkrētas valsts kriminālprocesuālo tiesību avotos. Tieši ar izmeklēšanas darbību veidu un satura aprakstu kriminālprocesa likumā tiek noteikti kritēriji noziedzīga nodarījuma izmeklēšanas laikā iegūto pierādījumu likumības izvērtēšanai. Aprakstot kriminālistikas sistēmu, Hanss Gross izšḳīis tikai trīs izmeklēšanas darbības - apskati, kratīšanu un pratināšanu. ${ }^{14}$ Mūsdienās izmeklēšanas darbību sistēmu Latvijā veido šādas izmeklēšanas darbības: pratināšana, aptauja, konfrontēšana, apskate, ekshumācija, aplūkošana, izmeklēšanas eksperiments, liecību pārbaude uz vietas, uzrādīšana atpazišanai, kratīšana, izn,emšana un ekspertīze.

Iedalot izmeklēšanas darbības atsevišḳā kriminālprocesuālo darbību grupā, Latvijā normatīi noteikti šādi izmeklēšanas darbību īstenošanas vispārīgi pamatnosacijumi:

1) Iepriekš plānojamas izmeklēšanas darbības parasti veic laikā no pulksten 8.00 lidz 20.00.

2) Izmeklēšanas darbības sākumā tās veicējs informē konkrētajā procesā iesaistīto personu par tās tiesībām un pienākumiem, kā arī brīdina par atbildību par savu pienākumu nepildīšanu.

3) Pret personu, kura piedalās izmeklēšanas darbībā, aizliegts lietot vardarbību, draudus, melus, kā arī citas pretlikumīgas un morāles normām neatbilstošas darbības vai tādas darbības, kas apdraud personas dzīvību vai veselību vai aizskar personas cienuu.

4) Aizliegts izpaust ziṇas par tās personas privāto dzīvi, kura piedalās izmeklēšanas darbībā, kā arī ziṇas, kas satur profesionālu noslēpumu vai komercnoslēpumu, izṇemot gadījumus, kad tas nepieciešams pierādī̌̌anā.

5) Izmeklēšanas darbību var veikt, izmantojot tehniskos līdzekḷus, kā arī, ja tas nepieciešams, pieaicinot ekspertu, revidentu vai speciālistu.

Kā jau iepriekš minēts, noziedzīga nodarījuma izmeklēšana tiek īstenota ar izmeklēšanas darbību kompleksa starpniecību. Izmeklēšanas darbības veikšanas būtība ir jaunu zināšanu iegūšana un pārbaude par izmeklējamo noziedzīgo nodarījumu.

14 Гросс Г. Руководство Аля судебных следователей как система криминалистики. Новое изА., перепеч. с изА. 1908 г., Москва: АексЭст, 2002, с. 74-181. 
Šādas pārbaudes kritēriji ir jauno zināšanu ticamība, piel̦aujamība un attiecināmība ${ }^{15}$. Tieši zināšanas par izmeklējamo noziedzīga nodarijuma notikumu un tā krimināltiesiskais novērtējums ir apsūdzības pamatā. Izvēle par labu vienas vai otras izmeklēšanas darbības veikšanai atkarīga no tā, vai noziedzīga nodarījuma izmeklēšanai nozīmīgu zināšanu ieguve ir optimāla, izmantojot tieši konkrēto izmeklēšanas darbību. Šì izvēle atspoguḷ zināšanu par noziedzīgā nodarījuma notikumu iespējamās iegūšanas formas sākotnējo novērtēšanu.

Kriminālistikā atkarībā no zināšanu, kas saistītas ar noziedzịgā nodarījuma notikuma pēdām, iegūšanas līdzekḷu un veidu kopuma, izmeklēšanas darbības iedalāmas šādās grupās:

1) izmeklēšanas darbības, kas saistìtas ar piespiedu novērošanu (apskate, aplūkošana, izmeklēšanas eksperiments);

2) izmeklēšanas darbības, kas saistitas ar grūti pieejamu novērošanu (kratišana, izñemšana, ekshumācija);

3) izmeklēšanas darbības, kas saistittas ar iztaujāšanu (pratināšana, aptauja, konfrontēšana, uzrādī̌̌na atpazišanai, liecību pārbaude uz vietas);

4) izmeklēšanas darbības, kas saistītas ar procesa virzìtājam slēptas informācijas izpēti (ekspertīze).

Izñemot ekspertīzi, visas pārējās izmeklēšanas darbības pię̧auj iespēju procesa virzītājam tieši uztvert un fiksēt noziedzīgā nodarījuma pēdas. Savukārt ekspertīze pamatojas uz zināšanu par noziedzīga nodarījuma pēdām pastarpinātu iegūšanu. Šīs zināšanas procesa virzītājs iegūst nevis pats, bet ar eksperta, kas parasti procesa virzītāja uzdevumā veic speciālu izpēti, palīdzību.

Visu izmeklēšanas darbību teorētiskais pamats ir mūsdienu novērošanas, eksperimenta, salīdzināšanas, mērī̌̌anas un modelēšanas teorijas. Tāpēc izmeklēšanas darbỉbu logiskajā apjomā ietilpst tikai tādas kriminālprocesuālās darbības, kuru pamatā liktas mūsdienu zinātniskās zināšanas par novērošanu, eksperimentu, salīdzināšanu, mērîšanu un modelēšanu. ${ }^{16}$ Tieši šis kritērijs ḷauj skaidri iedalīt izmeklēšanas darbỉbas atsevišķā specifiskā grupā, un tieši ar šo kritēiiju nosacìta izmeklēšanas darbību veikšanas zinātniskās pamatotības novērtēšana. Saistībā ar šo apstākli ukrainu kriminālists V. Šepitjko pareizi atzinis, ka kriminālistiskās rekomendācijas, kas neatbilst zinātniskuma prasībām un ir pretrunā ar demokrātiskiem tiesvedības principiem kriminālprocesā, nevar pildìt savas funkcijas un tām nav vietas noziedzịgu nodarījumu izmeklēšanas praksê.. ${ }^{17}$

Iepriekš minētās kriminālistiskās darbības īpatnības saistībā ar izzinošo darbību, kuras virzìtas uz ar noziedzīgā nodarījuma notikumu saistīto apstākḷu noskaidrošanu, logisko apjomu un saturu veido jēdziena "kriminālistiskā taktika" apjomu un saturu. Atsevišķas izmeklēšanas darbības veids un saturs, kas tiek noteikts normatīvi katrā valstī, ir noteicošais konkrētas izmeklēšanas darbības taktikas izvēlē; tādā veidā pastāv

15 Sỉkāk sk.: Терехович В. Н., Ниманде Э. В. Проблема истинностного и ценностного в криминалистическом познании. Теорія та практика судової експертизи і кріміналістики. 36. наук. праць. Вип. 10, Харьков: Право, 2010, с. 36-43. Терехович В. Н., с. 41-43.

16 Sīkāk sk.: Терехович В. Н., с. 174-203.

17 Шепитько В. Ю. Криминалистическая тактика Современное состояние и перспективы развития. Grām.: Шепитько В. Ю. Избранные труды. Харьков: Апостиль, 2010, с. 162. 
pratināšanas taktika, izmeklēšanas eksperimenta taktika un citu izmeklēšanas darbību taktika, un tādējādi atseviškłu izmeklēšanas darbïbu veikšanas taktiku likumsakarību kopums veido kriminālistisko taktiku - kriminālistikas teorijas sevišķās daḷas sadaļu, kurā aprakstìtas un skaidrotas izmeklěšanas darbību istenošanas likumsakarības. Tāpēc dažu autoru mēǵinājumiem "iemontēt" kriminālistikas terminolog̣ijā terminus "tiesu taktika", "advokātu taktika” vai "prokuroru taktika" un citus šāda veida jaundarinājumus nav nekā kopīga ar noziedzīgu nodarījumu izmeklēšanu mūsdienu kriminālprocesā, un uz kriminālistiku tie nebūtu attiecināmi, bet ir uzskatāmi par kriminālistikas terminologiijas piesārņošanu.

\section{Kopsavilkums}

1. Kriminālistikas terminolog̣ijas unifikācijas rezultātā mūsdienās kriminālistikas mācību grāmatās tiek izmantots tikai termins "kriminālistiskā taktika". Terminolog̣ijas izmaiñas šajā kriminālistikas dạāa notika ne tikai kriminālprocesa attīstības rezultātā, bet arī kā sekas priekšstatu izmaiņām par noziedzīgu nodarījumu izmeklēšanas būtỉbu.

2. Kriminālistikā izzinošo darbību sistēmai arī ir savas likumsakarības, un tā iedalāma īpašā jēdzienu grupā. Kriminālistisko zināšanu iegūšanas un uzbūves logiika prasa skaidri apzīmēt šo darbību apjomu un formulēt to saturu. Kriminālistiskajā izzināšanā darbību sistēmas īpatnība ir tāda, ka noziedzīga nodarījuma izmeklěšanas nosacijjumi jau vēsturiski tiek formulēti kriminālprocesa aprakstā.

3. Izmeklēšanas darbības ir kriminālprocesuālo darbību paveids, un tās tieši virzìtas uz to apstākḷu pēdu atklāšanu, kuri saistîti ar noziedzīga nodarijuma notikumu. Izdalot no kriminālprocesuālo darbību grupas atsevišķu darbỉbu grupu - izmeklēšanas darbïbas, tiek sasniegta noteiktỉba ne tikai izmeklēšanas darbïbu izpratnē, bet arī izmeklēšanas darbību saturā un logiiskajā apjomā. Izmeklēšanas darbību daba nosacìta ar to, ka, pirmkārt, izmeklēšanas darbības ir mērķtiecīgas darbỉbas, t. i., tās orientētas uz saprātīga mērķa sasniegšanu - noskaidrot apstākḷus, kas saistīti ar noziedzīgu nodarījumu; otrkārt, izmeklēšanas darbības ir vērtību un racionālas darbības, jo tās vispirms orientētas uz juridiskām vērtībām, t. i., uz noziedzịga nodarījuma notikuma un ar to saistīto apstākḷu juridisku izpratni.

4. Izmeklēšanas darbību teorētiskais pamats ir mūsdienu novērošanas, eksperimenta, salīdzināšanas, mērī̌šnas un modelēšanas teorijas. Tāpēc izmeklēšanas darbỉbu logiiskajā apjomā ietilpst tikai tādas kriminālprocesuālās darbības, kuru pamatā liktas mūsdienu zinātniskās zināšanas par novērošanu, eksperimentu, salīdzināšanu, mērišanu un modelēšanu. Tieši šis kritērijs l̦auj skaidri iedalït izmeklēšanas darbības atsevišķāa specifiskā grupā, un tieši ar šo kritēriju nosacìta izmeklēšanas darbību veikšanas zinātniskās pamatotības novērtēšana.

5. Kriminālistiskās darbības īpatnības saistībā ar izzinošo darbību, kuras virzìtas uz ar noziedzīgā nodarījuma notikumu saistīto apstākḷu noskaidrošanu, logiisko apjomu un saturu, veido jēdziena "kriminālistiskā taktika" apjomu un saturu. Atsevišķu izmeklēšanas darbību veikšanas taktiku likumsakarību kopums veido kriminālistisko taktiku - kriminālistikas teorijas seviškāās daļas sadaļu, kurā aprakstītas un skaidrotas izmeklēšanas darbību îstenošanas likumsakarības. 


\section{BIBLIOGRĀFIJA}

1. Ackermann R., Clages H., Roll H. Handbuch der kriminalistik. Kriminalistik fuer Praxis und Ausbildung. 2 Aufl. Richard Boorberg Verlag, 2003.

2. Kriminalistik Lexicon. Kriminalistik Verlag, Heidelberg, 1996.

3. Васильев А. Н. Основы следственной тактики. Автореферат Аисс., Москва, 1960.

4. Вейнгарт А. Уголовная тактика. Руководство к расследованию преступлений. Санктпетербург: Овруч, 1910.

5. Винберг А. И. О научных основах криминалистической тактики. Правоведение. Но. 3. Москва, 1965.

6. Гросс Г. Руководство аля судебных следователей как система криминалистики. Новое изА., перепеч. с изА. 1908 г., Москва: АексЭст, 2002.

7. Криминалистика. Техника и тактика расследования преступлений. Учебник. Москва, 1938.

8. Ниманде Э. В., Терехович В. Н. Проблема истинностного и ценностного в криминалистическом познании. Теорія та практика судової експертизи і кріміналістики. 36. наук. праць. Вип. 10, Харьков: Право, 2010.

9. Терехович В. Н. Теория криминалистики. Общая часть. Рига: [b.i.], 2015.

10. Шепитько В. Ю. Криминалистическая тактика Современное состояние и перспективы развития. In.: Шепитько В. Ю. Избранные труды. Харьков: Апостиль, 2010.

11. Якимов И. Н. Криминалистика уголовная тактика. 2-е изА., Москва, 1929.

\section{Normativie akti}

12. Krimināllikums: LV Likums. Latvijas Vēstnesis. 99/200 (1260/1261), 08.07.1998.

13. Kriminālprocesa likums: LV Likums. Latvijas Vēstnesis. 74 (3232), 11.05.2005.

14. Ministru kabineta 23.01.2018. noteikumu Nr. 49 "Noteikumi par Latvijas zinātnes nozarēm un apakšnozarēm” pielikuma 5.5. apakšpunkts. Latvijas Vēstnesis. 18 (6104), 25.01.2018. 